\title{
Pharmacological potentials and toxicity effects of Excoecaria agallocha
}

\author{
Eric Wei Chiang Chan ${ }^{1 *}$, Nozomi Oshiro ${ }^{2}$, Mio Kezuka ${ }^{2}$, Norimi Kimura ${ }^{2}$, Karin Baba $^{2}$, Hung Tuck Chan ${ }^{2}$ \\ ${ }^{1}$ Faculty of Applied Sciences, UCSI University, Cheras 56000, Kuala Lumpur, Malaysia. \\ ${ }^{2}$ Secretariat, International Society for Mangrove Ecosystems (ISME), c/o Faculty of Agriculture, University of the Ryukyus, Okinawa, 903-0129, Japan.
}

\begin{tabular}{|c|c|}
\hline ARTICLE INFO & ABSTRACT \\
\hline $\begin{array}{l}\text { Article history: } \\
\text { Received on: } 02 / 12 / 2017 \\
\text { Accepted on: } 25 / 02 / 2018 \\
\text { Available online: } 30 / 05 / 2018\end{array}$ & $\begin{array}{l}\text { Excoecaria agallocha is commonly found on the landward side of mangroves. Belonging to the family Euphorbiaceae, } \\
\text { trees are deciduous with leaves turning orange or red before shedding. The species produces white latex that is } \\
\text { toxic, causing skin blistering and temporary blindness. The toxic E. agallocha latex which causes skin irritation } \\
\text { and blistering has been attributed to three groups of diterpene esters of the daphnane and tigliane types. Classes } \\
\text { of compounds of E. agallocha include diterpenoids, flavonoids, phenolic acids, sterols, tannins, and triterpenoids. }\end{array}$ \\
\hline $\begin{array}{l}\text { Key words: } \\
\text { Excoecaria agallocha, } \\
\text { Phytochemistry, } \\
\text { Pharmacology, Diterpenoids, } \\
\text { Toxic Latex, } \\
\text { Case Report. }\end{array}$ & $\begin{array}{l}\text { The most common chemical constituents are diterpenoids which are of the labdane, artisane, beyerane, daphnane, } \\
\text { tigliane, isopimarane and kaurane types. Commonly isolated diterpenoids include agallochaexcoerins, agallochaols, } \\
\text { agallochins, excoeagallochaols, and excoecarins. Pharmacological properties of E. agallocha include antioxidant, } \\
\text { antibacterial, antiviral, larvicidal, hedgehog signalling inhibition, anticancer, anti-inflammatory and analgesic } \\
\text { activities. Other bioactivities include anti-ulcer, anti-diabetic, non-specific immunity, disease resistance, sedative, } \\
\text { gastro-protective, anti-allergic and anti-hyperglycemic effects. A case report of a 15-year-old boy from Sri Lanka, } \\
\text { splashed with a toxic latex of E. agallocha and admitted to the General Hospital in Matara, is presented. }\end{array}$ \\
\hline
\end{tabular}

\section{INTRODUCTION}

The genus Excoecaria of the family Euphorbiaceae comprises 37 tree species with acceptable names (The Plant List, 2013). Trees are distributed throughout tropical Africa, Asia and Australia of which E. agallocha and E. indica occur in the mangroves (Duke, 2006; Yin et al., 2008). Several references are of direct relevance to the present review on E. agallocha. They are chemical constituents of plants from the genus Excoecaria (Yin et al., 2008); the chemistry and bioactivities of natural products from semi-mangrove flora (Li et al., 2009); E. agallocha (Euphorbiaceae): an overview (Rajeswari and Rao, 2015); an insight on E. agallocha (Kaliamurthi and Selvaraj, 2016); and ethnobotany, phytochemistry and pharmacology of E. agallocha (Mondal et al., 2016).

Excoecaria agallocha $\mathrm{L}$. is a small deciduous tree up to 10-12 m tall (Duke, 2006; Giesen et al., 2007; Mondal et al.,

\section{"Corresponding Author}

Eric Wei Chiang Chan, Associate Professor, Faculty of Applied Sciences, UCSI University, Cheras, Kuala Lumpur, Malaysia.

Email: chanwc@ucsiuniversity.edu.my; erchan@yahoo.com
2016). Trees are multi-stemmed and produce a copious amount of white latex, which is toxic, causing skin blistering and temporary blindness. The bark is greyish with vertical fissures and lenticels. Leaves are opposite, ovate or elliptic with a toothed margin and have two basal glands. They turn orange or red when old before shedding (Figure 1). The species is dioecious i.e. having male and female trees. Male flowers are larger than female flowers and scented (Figure 2). Fruits are a three-lobed capsule with dark brown or black seeds, resembling pepper corn. Commonly found at the landward side of mangroves, E. agallocha the species is distributed from South, Southeast and East Asia extending to Australia and the west Pacific (Duke, 2006; Giesen et al., 2007). In China, the species is widely distributed along the southern coast, stretching from Zhejiang to Guangxi and Hainan (Li et al., 2010). Trees of E. agallocha grow gregariously with abundance varying from 170 stems/ha at Tok Bali in Kelantan, Malaysia (Kasawani et al., 2007) to 533 stems/ha in the Sundarbans, Bangladesh (Kamruzzaman et al., 2018), and to 1294 stems/ha in Kerala, India (Vijayan et al., 2015). Closely related is E. agallocha is E. indica, which is monoecious i.e. having male and female flowers on the same tree (Ragavan et al., 2015). 


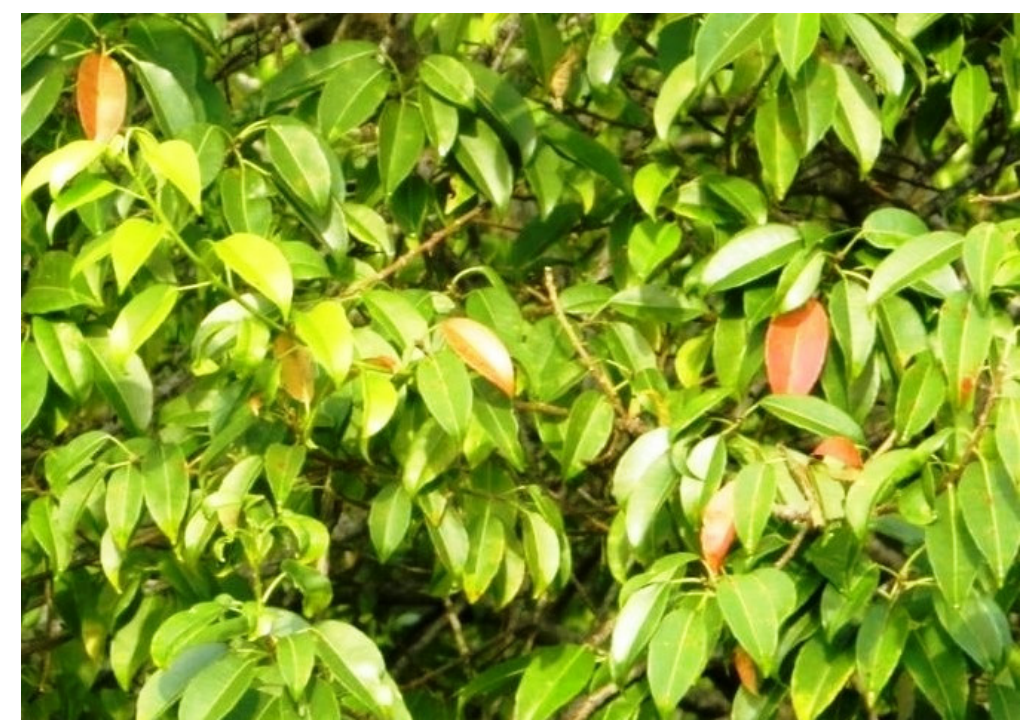

Fig. 1: Foliage of Excoecaria agallocha with old leaves turning orange or red.
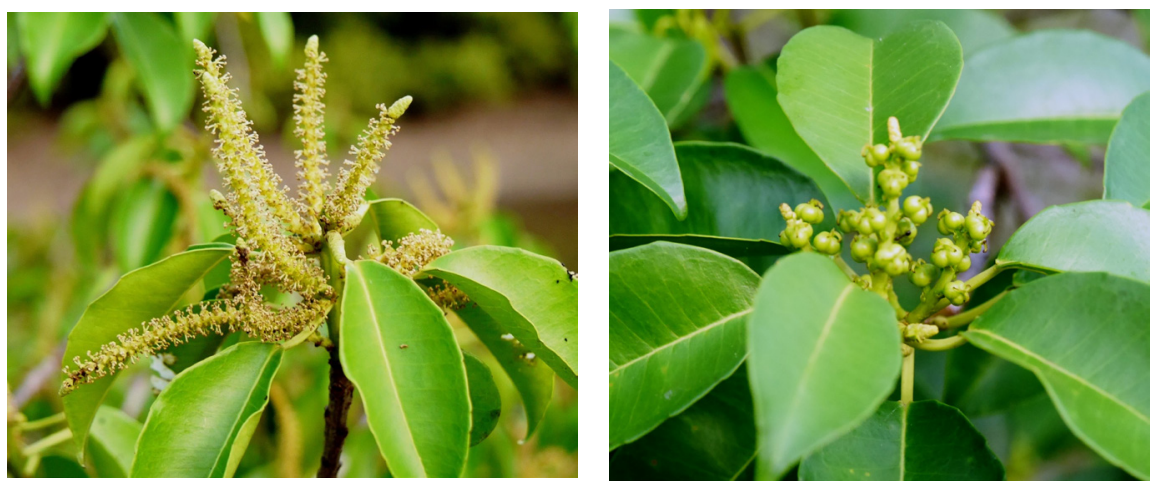

Fig. 2: Male flowers (left) and female flowers (right) of Excoecaria agallocha.

Trees of E. agallocha have religious significance. At the Hindu temple of Chidambaram in India, the local community prays to the species as sacred plants (Kaliamurthi and Selvaraj, 2016; Agoramoorthy et al., 2007). The first newsprint mill in Bangladesh was located along the Bhairab river at Khalishpur in Khulna (Alam, 2006; Baba et al., 2013). The mill, which started operation in 1959, used E. agallocha (gewa) wood as raw material. The toxic latex of E. agallocha is known to cause skin irritation and blistering, and temporary blindness (Laith and Najiah, 2014). In countries of Southeast Asia, the latex has been used as fish poison. In Thailand, its bark and wood have been used as traditional medicine to treat flatulence (Karalai et al., 1994). The plant is traditionally used for the treatment of ulcers, rheumatism, leprosy, and paralysis in the coastal regions of South China (Li et al., 2012). In Okinawa, Japan, the resinous E. agallocha wood has been used to substitute agarwood (jinko) as incense (Konoshima et al., 2001).

\section{PHYTOCHEMISTRY}

Classes and names of compounds isolated from various plant parts of E. agallocha are listed in Table 1. Classes of compounds include diterpenoids, flavonoids, phenolic acids, sterols, tannins, and triterpenoids. The most common chemical constituents of E. agallocha are diterpenoids, which have been isolated from the wood, bark, roots, leaves, and stems. Diterpenoids are of the labdane, artisane, beyerane, daphnane, tigliane, isopimarane and kaurane types (Yin et al., 2008; Li et al., 2009; Mondal et al., 2016). Commonly isolated diterpenoids include agallochaexcoerins, agallochaols, agallochins, excoeagallochaols, and excoecarins. From the leaves and stems of E. agallocha, triterpenoids, flavonoids, phenolic acids, sterols, and tannins have also been reported (Table 1). Triterpenoids are of the oleanane, taraxerane, friedelane, cycloartane and lupane types (Yin et al., 2008; Mondal et al., 2016). Flavonoids include catechin, kaempferol, myricetin and quercetin, and their derivatives. Recently, two new lasiodiplodins together with three known analogues, were isolated from Lasiodiplodia sp. 318, an endophytic fungus from E. agallocha (Huang et al., 2017). Lasiodiplodins are compounds with a resorcinol moiety fused to a 14/12-member macrocyclic lactone ring. 
Table 1: Classes and names of compounds isolated from Excoecaria agallocha.

\begin{tabular}{|c|c|}
\hline Compound class and name (plant part) & (Reference) \\
\hline \multicolumn{2}{|l|}{ Diterpenoids } \\
\hline 2-Acetoxybeyera-1,15-diene-3,12-dione (root) & (Anjaneyulu et al., 2002) \\
\hline Agallochaexcoerins D-F* (wood) & (Ponnapalli et al., 2013) \\
\hline Agallochaols A, B, D-F, G-J, K-P, Q (leaf, stem, twig) & (Wang et al., 2004; 2005; 2006; Li et al., 2010) \\
\hline Agallochaone A* (leaf, stem) & (Li et al., 2007) \\
\hline Agallochins A-L, O* (root, leaf, stem) & $\begin{array}{l}\text { (Anjaneyulu and Rao, 2000; 2003; Anjaneyulu et al, 2002; 2003; } \\
\text { Wang et al., 2004; 2005; Li et al., 2010) }\end{array}$ \\
\hline ent-Atisane-3 $\beta, 16 \alpha$-diol (bark) & (Wang et al., 2009) \\
\hline ent-17-Caffeoyloxykaur-15-en-3-one (stem, twig) & (Li et al., 2010) \\
\hline 7-Deoxogeayine (stem, twig) & (Li et al., 2010) \\
\hline$(13 R, 14 R)$-ent-8 $\alpha, 13,14,15$-Diepoxy-13-epi-labda-3 $\beta$-ol (wood) & (Konishi et al., 2003c) \\
\hline ent-3 $\alpha, 11 \beta$-Dihydroxy-ent-isopimara-8(14),15-dien-2-one* (wood) & (Kang et al., 2005) \\
\hline 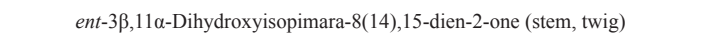 & (Li et al., 2010) \\
\hline ent-15,18-Dihydroxylabd-8(17),13E-diene (stem, twig) & (Li et al., 2010) \\
\hline ent-15,16-Epoxybeyeran-3 $\alpha$-ol (wood) & (Konishi et al., 2003b) \\
\hline Excoagallochaols A-D* (leaf, stem) & (Wang et al., 2007; Liu et al., 2010) \\
\hline $\begin{array}{c}\text { Excoecarins A-F, G1, G2, H, K, M, N, R1, R2, S, T1, T2, } \\
\text { V1-V3* (wood, leaf, stem) }\end{array}$ & $\begin{array}{c}\text { (Konishi et al., 1996a; 1998a; 1998b; 1999; 2000a; 2000b; 2003a; 2003b; 2003c; } \\
\text { Wang et al., 2005; Li et al., 2007) }\end{array}$ \\
\hline Excolides A, B (stem) & (Annam et al., 2015) \\
\hline 11-epi-Excolide A (stem) & (Annam et al., 2015) \\
\hline 11,13-di-epi-Excolide A (stem) & (Annam et al., 2015) \\
\hline ent-(14S)-8,13-Epoxy-14,15-dihydroxylabdan-3-one* (wood) & (Konishi et al., 1998a) \\
\hline ent-8,13-Epoxy-2-hydroxy-13-epilabda-1,14-dien-3-one* (wood) & (Konishi et al., 1998a) \\
\hline ent-(1R)-8,13-Epoxy-2-oxa-3-oxo-13-epilabd-14-ene-1- carboxylic acid* (wood) & (Konishi et al., 1998a) \\
\hline ent-13-epi-8,13-Epoxy-2,3-secolabd-14-ene-2,3-dioic acid* (wood) & (Konishi et al., 1998a) \\
\hline ent-13-epi-8,13-Epoxy-2,3-secolabd-14-ene-2,3-dioic acid 3-methyl ester* (wood) & (Konishi et al., 1998a) \\
\hline 8,13-Epoxy-14-labden-3-one (leaf, stem) & (Li et al., 2007) \\
\hline ent-16 $\alpha$-Hydroxy-atisane-3,4-lactone* (bark) & (Wang et al., 2009) \\
\hline ent-16a-Hydroxy-atisane-3-one* (wood, bark) & (Kang et al., 2005; Wang et al., 2009) \\
\hline ent-3,4-seco-16 $\alpha$-Hydroxyatis-4(19)-en-3-oic acid (bark) & (Wang et al., 2009) \\
\hline 2-Hydroxybeyera-1,15-diene-3,12-dione (root) & (Anjaneyulu et al., 2002) \\
\hline ent-3ß-Hydroxybeyer-15-en-2-one (wood) & (Konishi et al., 2000b) \\
\hline ent-3 $\beta$-Hydroxybeyer-15-ene-2,12-dione (wood, stem, twig) & (Kang et al., 2005; Li et al., 2010) \\
\hline ent-3 $\beta$-Hydroxy-15-beyeren-2-one (wood) & (Konishi et al., 2003c) \\
\hline ent-17-Hydroxykaur-15-en-3-one (stem, twig) & (Li et al., 2012) \\
\hline ent-16-Hydroxykauran-3-one (root) & (Anjaneyulu et al., 2002) \\
\hline ent-15-Hydroxy-labda-8(17),13E-dien-3-one (wood, stem, twig) & (Konishi et al., 1996a; Li et al., 2010) \\
\hline ent-11 $\alpha$-Hydroxy-3-oxo-13-epi-manoyl oxide (wood) & (Konishi et al., 1996a) \\
\hline ent-16-Hydroxy-3-oxo-13-epi-manoyl oxide (wood) & (Konishi et al., 1996a) \\
\hline ent-Kaur-15-en-3ß,17-diol (stem, twig) & (Li et al., 2010) \\
\hline ent-13-epi-Manoyl oxide (wood) & (Konishi et al., 1996a) \\
\hline ent-12-oxo-2,3-Secobeyer-15-ene-2,3-dioic acid (wood) & (Konishi et al., 2003b) \\
\hline ent-2,3-Secobeyer-15-ene-2,3-dioic acid (stem) & (Konishi et al., 2003c) \\
\hline Ribenol (wood) & (Konishi et al., 1996a) \\
\hline Ribenone (wood) & (Konishi et al., 1996a) \\
\hline Stachenol (wood) & (Konishi et al., 2000b) \\
\hline Stachenone (wood) & (Konishi et al., 2000b) \\
\hline \multicolumn{2}{|l|}{ Flavonoids } \\
\hline Afzelin (leaf) & (Rifai et al., 2011) \\
\hline (+)-Catechin (stem, twig) & (Li et al., 2012) \\
\hline$(+)$-Catechin-3-O- $\beta$-D-glucopyranoside (stem, twig) & (Li et al., 2012) \\
\hline (+)-Catechin-7-O- $\beta$-D-glucopyranoside (stem, twig) & (Li et al., 2012) \\
\hline
\end{tabular}


Catechin hydrate (bark)

(+)-Catechin-3- $O$ - $\alpha$-L-rhamnose (stem, twig)

Compounds 1, 2 (flavonoid glycosides)* (leaf)

Excoecariphenols A-D* (stem, twig)

$(2 R, 3 S)$-Gallocatechin (stem, twig)

Isorhamnetin (leaf)

Kaempferide 3-O- $\alpha$-L-rhamnopyranoside (leaf)

Kaempferol (leaf)

Kaempferol-3-O-(2-O-acetyl- $\alpha$-L-rhamnopyranoside (leaf)

Kaempferol 3-O- $\alpha$-L-arabinofuranoside (leaf)

Luteolin (leaf)

Myricetin (leaf)

Myricetin-3-O-(6-O-galloyl)- $\beta$-glucopyranoside (stem, twig)

$(2 R, 3 R)-3,5,7,3^{\prime}, 5^{\prime}$-Pentahydroxyflavanonol-3- $O$ - $\alpha$-L-rhamno pyranoside* (stem)

Quercetin (leaf)

Quercetin-3-O-(6-O-galloyl)- $\beta$-gallcopyranoside (stem, twig) Quercetin-3-O-(6-O-galloyl)- $\beta$-glucopyranoside (stem, twig)

Quercetin-3-O- $\beta$-galactopyranoside (stem, twig)

Quercetin-3-O- $\beta$-glucopyranoside (stem, twig)

Quercitrin (leaf)

Rutin (leaf)

Phenolic acids

Ellagic acid (bark)

Gallic acid (stem, twig, bark)

Vanillic acid (bark)

\author{
(Jahan et al., 2014) \\ (Li et al., 2012) \\ (Rifai et al., 2011) \\ (Li et al., 2012) \\ (Li et al., 2012) \\ (Selvaraj et al., 2014) \\ (Rifai et al., 2011) \\ (Selvaraj et al., 2014) \\ (Rifai et al., 2011) \\ (Rifai et al., 2011) \\ (Selvaraj et al., 2014) \\ (Selvaraj et al., 2014) \\ (Li et al., 2012) \\ (Konishi et al., 2003c) \\ (Selvaraj et al., 2014) \\ (Li et al., 2012) \\ (Li et al., 2012) \\ (Li et al., 2012) \\ (Li et al., 2012) \\ (Rifai et al., 2011)
}

(Rifai et al., 2011; Selvaraj et al., 2014)

(Jahan et al., 2014)

(Li et al., 2012; Jahan et al., 2014)

(Jahan et al., 2014)

(Tian et al., 2008)

(Tian et al., 2008)

(Anjaneyulu et al., 1993; Tian et al., 2008)
(Li et al., 2012)

(Li et al., 2012)

(Li et al., 2012)

(Li et al., 2012)

(Li et al., 2012)

(Li et al., 2012)

(Li et al., 2012)

(Li et al., 2012)

(Li et al., 2012)

(Li et al., 2012)

(Li et al., 2012)

(Li et al., 2012)

(Konishi et al., 2003c)

(Li et al., 2012)

4-O-Xylopyranoside (stem, twig)

(Anjaneyulu et al., 1993)

(Tian et al., 2008)

3ß-Acetoxytaraxer-14-en-28-oic acid (wood)

Acetylaleuritolic acid (stem, twig)

(Kawashima et al., 1971)

$\beta$-Amyrenone (latex)

$\beta$-Amyrin (wood, latex)

epi- $\alpha$-Amyrin (stem)

(Kawashima et al., 1971; Anjaneyulu et al., 1993)

(Liu et al., 2010)

epi- $\beta$-Amyrin (wood, stem, latex)

(Kawashima et al., 1971; Anjaneyulu et al., 1993; Liu et al., 2010)

$\beta$-Amyrin acetate (leaf, stem, twig) Betulin (stem)

(Zou et al., 2006; Tian et al., 2008)

(Liu et al., 2010) 


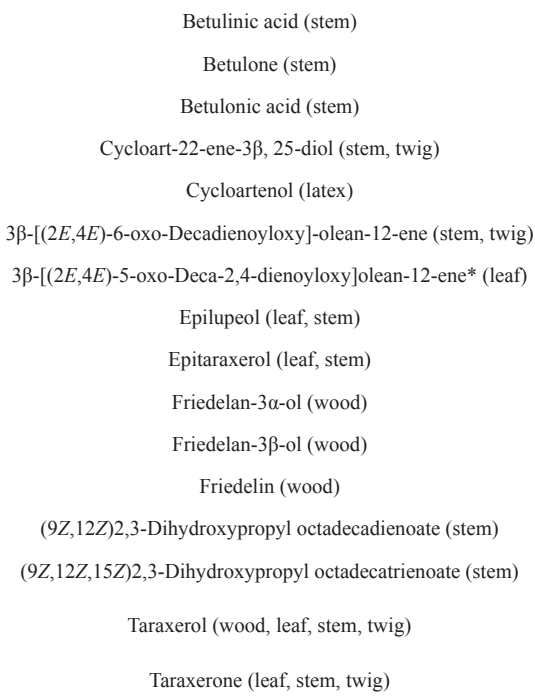

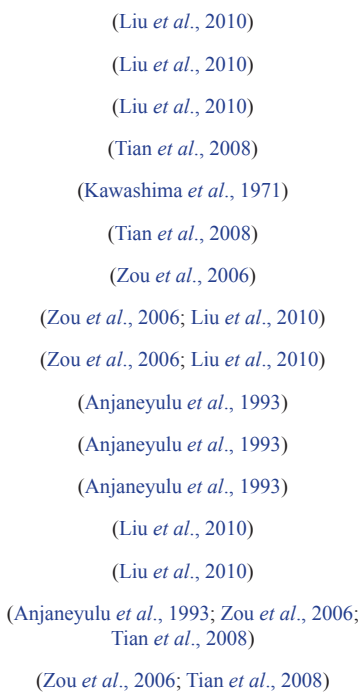

(Zou et al., 2006; Tian et al., 2008)

\footnotetext{
* New to Excoecaria agallocha.
}

\section{PHARMACOLOGICAL POTENTIALS}

\section{Antioxidant and antibacterial}

Studies have shown that the leaf (Patra et al., 2009; Poorna et al., 2012; Deepa et al., 2015; Laith et al., 2016) and bark (Subhan et al., 2008a; Hossain et al., 2009) extracts of E. agallocha possess significant antioxidant activities when assessed using well-established assays. Based on 2,2-diphenyl1-picrylhydrazyl (DPPH) free radical scavenging of different plant parts extracted with different solvents, the ranking was as follows: leaf $>$ root $>$ stem, and methanol $>$ ethyl acetate $>$ ethanol $>$ chloroform (Sofia and Teresa, 2016). Similarly, studies have shown that leaf (Agoramoorthy et al., 2007; Vadlapudi et al., 2009; Raja et al., 2010; Laith and Najiah, 2014; Deepa et al., 2015; Laith et al., 2016) and bark (Subhan et al., 2008b) extracts of E. agallocha inhibited bacterial growth. Of interest was the inhibition of bacteria causing fish-related diseases (Laith and Najiah, 2014; Laith et al., 2016). One such study reported that the bark extract of E. agallocha $(1-3 \mathrm{mg} / \mathrm{ml})$ exhibited no antibacterial activity against bacteria from clinical isolates (Rajia et al., 2006). Recently, the antibacterial activity of E. agallocha bark extract (500 $\mu \mathrm{g} /$ disc) (Shanmugapriya and Ramanathan, 2015) and of silver nanoparticles of E. agallocha fruit extract have been reported (Nagababu and Rao, 2017). Another interesting study was on the anti-quorum sensing and anti-biofilm properties of $E$. agallocha leaf extract on Pseudomonas aeruginosa (Karuppiah and Thiruganasambandam, 2017). At $2 \mathrm{mg} / \mathrm{ml}$, the leaf extract inhibited violacein production, biofilm formation including motility behaviour of $P$. aeruginosa.

\section{Antiviral}

There was increasing research interest on E. agallocha when a novel phorbol ester (12-deoxyphorbol-13-[3E,5E]-deca3,5-dienoate) isolated from its leaves and stems was found to be a potent inhibitor of HIV-1 replication with an $\mathrm{IC}_{50}$ value of 6.0 $\mathrm{nm}$ (Erickson et al., 1995). Soon after, screening of mangrove plant extracts for anti-HIV activity in MT-4 cells showed that the ethanol leaf extract of E. agallocha displayed potent activity
(Premanathan et al., 1996). Values were 7.3 and $30 \mu \mathrm{g} / \mathrm{ml}$ for $50 \%$ inhibition of HIV activity and for $100 \%$ inhibition of HIV adsorption, respectively. Recently, the active ethanol stem fraction of $E$. agallocha was reported to inhibit the reverse transcriptase enzyme which is responsible for the synthesis of proviral DNA (Patil et al., 2011). The fraction showed 34\% of inhibition, comparable with the standard drug azidothymidine (36\%). When screened for inhibition of Epstein-Barr virus (EBV) in TPAactivated Raji cells, diterpenoids isolated from the wood of $E$. agallocha displayed stronger inhibitory effects than glycyrrhetic acid, an anti-tumour agent (Konoshima et al., 2001; Konishi et al., 1998c). Among the diterpenoids, ent-3 $\alpha$-hydroxy-beyer-15-ene-2one and excoecarin $\mathrm{S}$ exhibited the strongest anti-EBV activity. Polyphenols from the leaves of E. agallocha were evaluated for their inhibitory effects against hepatitis $\mathrm{C}$ virus (HCV) (Li et al., 2012). Results showed that excoecariphenol D and corilagin inhibited HCV NS3-4A protease with $\mathrm{IC}_{50}$ values of 6.9 and 3.5 $\mu \mathrm{M}$, and inhibited HCV RNA in Huh 7.5 cells with $\mathrm{EC}_{50}$ values of 12.6 and $13.6 \mu \mathrm{M}$, respectively.

\section{HS inhibition and anticancer}

Two new compounds (1 and 2) including six known flavonoid glycosides isolated from the leaves of E. agallocha were tested for hedgehog signalling (HS) inhibition, and for cytotoxicity against human pancreatic (PANC1) and prostate (DU145) cancer cells (Rifai et al., 2011). Compound 1 and kaempferol 3-O- $\alpha-\mathrm{L}-$ arabinofuranoside displayed HS inhibition with $\mathrm{IC}_{50}$ values of 0.5 and $2.0 \mu \mathrm{M}$, and cytotoxicity with $\mathrm{IC}_{50}$ values of 0.7 and $1.8 \mu \mathrm{M}$ against PANC1, and 0.8 and $2.4 \mu \mathrm{M}$ against DU145 cancer cells, respectively. The HS pathway is known to control cell growth and proliferation, and abnormal activation has been implicated in the development of certain types of cancer (Abidi, 2014). Methanol and chloroform leaf extracts of E. agallocha have been reported to be cytotoxic against Hep-2 cancer cells (Batsa and Periyasamy, 2013). Earlier, six triterpenoids ( $\beta$-amyrin acetate, epilupeol, epitaraxerol, $3 \beta-[(2 E, 4 E)-5$-oxodeca-2,4-dienoyloxy]olean-12ene, taraxerol, and taraxerone) isolated from the leaves of $E$. 
agallocha were found to be inactive $\left(\mathrm{IC}_{50}>50 \mu \mathrm{g} / \mathrm{ml}\right)$ against human cancer cells of A549, BGC-823, MCF-7, Bel-7402 and HCT-8 (Zou et al., 2006). Recently, it was reported that the ethanol stem extract of $E$. agallocha exerted a significant cytotoxic effect on pancreatic cancer cells of Capan-1 and Miapaca-2 with $\mathrm{IC}_{50}$ values of 4 and $7 \mu \mathrm{g} / \mathrm{ml}$, respectively, but was inactive against cells of BxPC-3 and PANC-1 (Patil et al., 2011). When the five lasiodiplodins were evaluated for in vitro cytotoxic activities, 2,4-dihydroxy-6-nonylbenzoate was the most potent with $\mathrm{IC}_{50}$ values of 5.3 and $13 \mu \mathrm{M}$ against rat cancer cells of MMQ and GH3, respectively (Huang et al., 2017). Structural-activity analysis indicated that the resorcinol-3-OH functional group contributed greatly to their cytotoxic activities.

\section{Anti-inflammatory and analgesic}

Diterpenoids including agallochaols isolated from stems and twigs of E. agallocha (Table 1) have been reported to possess anti-inflammatory activity ( $\mathrm{Li}$ et al., 2010). They displayed potency in suppressing tumour necrosis factor (TNF)- $\alpha$ and interleukin (IL)-6 induced by lipopolysaccharide (LPS) in mouse macrophage RAW 264.7 cells by blocking NF-kB activation or AP-1 activation. In another study, E. agallocha was assessed for anti-inflammatory and analgesic effects (Babuselvam et al., 2012). The latex, leaf and seed extracts of E. agallocha (250 and $500 \mathrm{mg} /$ $\mathrm{kg}$ ) displayed significant inhibition of carrageenan-induced rat paw oedema after 3 hours. Inhibition was $63 \%, 62 \%$ and $70 \%$, respectively. The seed extract also showed maximum inhibition of $57 \%$ in the cotton pellet-induced granuloma test. Using the acetic acid-induced writhing and tail immersion tests, the seed extract showed significant analgesic activity. Earlier, the bark extract of E. agallocha at $500 \mathrm{mg} / \mathrm{kg}$ was reported to show significant reduction of $54 \%$ in acetic acid-induced writhing of mice (Subhan et al., 2008c). Recently, the antinociceptive effect of E. agallocha leaf extract (alkaline chloroform fraction) was attributed to rutin (Selvaraj et al., 2014). Docking simulation demonstrated that rutin interacted strongly with cyclooxygenase, forming a number of specific hydrogen bonds.

\section{Other bioactivities}

Leaf extracts of E. agallocha have anti-ulcer effect on NSAID-induced gastric ulcer rats (Thirunavukkarasu et al., 2009), anti-diabetic activity in alloxan-induced diabetic mice (Thirumurugan et al., 2009), enhance the non-specific immunity and disease resistance of fish (Laith et al., 2017), and inhibition of elastase and collagenase (Satyavani et al., 2018). The sedative effect on sodium thiopental injected mice (Subhan et al., 2008b), gastro-protective activity in albino mice (Subhan et al., 2008c), and anti-allergic activity in rat peritoneal exudate cells (Hossain et al., 2009) have been reported in the bark extracts of E. agallocha. Recently, the stem extract of E. agallocha has been reported to possess anti-hyperglycemic activity in glucose-loaded albino mice (Rahman et al., 2010).

\section{TOXIC EFFECTS}

\section{Larvicidal}

Of the different extracts of E. agallocha aerial parts (methanol, ethanol, hexane, chloroform and aqueous) evaluated for mosquito larvicidal activity, the methanol extract exhibited significant inhibition against Aedes aegypti and Culex quinquefasciatus larvae (Thirunavukkarasu et al., 2011; Pradeepa et al., 2015). Another recent study reported that $100 \%$ mortality of $A$. aegypti, C. quinquefasciatus and Anopheles stephensi larvae was observed at 1200, 300 and $300 \mathrm{ppm}$ of E. agallocha latex after $24 \mathrm{~h}$ exposure (Mendhulkar et al., 2017). The methanol leaf extract of E. agallocha showed significant anti-filarial activity against the various stages of development of Setaria digitata, a metazoan filarial parasite (Patra et al., 2009). After $24 \mathrm{~h}$ of treatment with the extract at 10, 50 and $100 \mu \mathrm{g} / \mathrm{ml}, 30 \%, 75 \%$, and $90 \%$ of the parasite were found dead, respectively. The bark extract of E. agallocha resulted in the lethality of brine shrimp larvae with $\mathrm{LC}_{50}$ value of $504 \mu \mathrm{g} / \mathrm{ml}$ and $\mathrm{LC}_{90}$ value of $800 \mu \mathrm{g} / \mathrm{ml}$ (Shanmugapriya and Ramanathan, 2015).

\section{Case report}

A 15-year-old boy from the coastal suburb of southern Sri Lanka was splashed with toxic latex when cutting the branches of an E. agallocha tree (Kumarasinghe and Seneviratne, 1998). Within minutes, the boy experienced burning pain in the right eye, and in parts of the face, body and limbs contacted with the latex. He was admitted to the ophthalmology ward of the General Hospital in Matara. Ophthalmological examinations revealed superficial burns of the right eyelids, cornea and conjunctiva. Dermatological examination, two days later, showed erythema and oedema around the right eye and forehead, and blistering of the skin of the face, body, and limbs. On treatment with amoxycillin and paracetamol along with topical application of an antibiotic ointment containing neomycin, bacitracin, and polymyxin, the boy was discharged after five days. When reviewed after a month, the eye had normalized but the skin showed minor scarring and hypopigmentation. This case report on the toxic effects of E. agallocha latex was presented at the $19^{\text {th }}$ World Congress of Dermatology held in June 1997, Sydney, Australia (Kumarasinghe and Seneviratne, 1998). In an earlier study, the toxic E. agallocha latex which causes skin irritation and blistering has been attributed to three groups of diterpene esters of the daphnane and tigliane types (Karalai et al., 1994). All three groups exhibited no irritant activity on the mouse ear but when trans-esterified with alkali, these cryptic irritants become highly toxic Excoecaria factors.

\section{CONCLUSION}

In the mangroves, two species of Excoecaria occur. Information of the phytochemistry and pharmacological potentials of E. agallocha will serve as useful reference for $E$. indica, which is poorly studied. The latex of E. agallocha warrants further research before considering the beneficial pharmacological properties of the species. Notably are the toxic effects of the latex on humans, and on terrestrial and aquatic fauna of the mangroves.

\section{ACKNOWLEDGMENT}

The authors are grateful to Prof Shigeyuki Baba, Executive Director of the International Society for Mangrove Ecosystems (ISME) for the photographs of male and female flowers of E. agallocha.

\section{REFERENCES}

Abidi A. Hedgehog signaling pathway: A novel target for cancer therapy. Indian J Pharmacol. 2014; 46:3-12. 
Agoramoorthy G, Chandrasekaran M, Venkatesalu V, Hsu MJ. Antibacterial and antifungal activities of fatty acid methyl esters of the blind-your-eye mangrove from India. Brazil J Microbiol. 2007; 38:739-742.

Alam M. Khulna newsprint mill. In: Banglapedia, 2006. Available at http://www.banglapedia.org/http/docs/ht/k_0250.htm.

Anjaneyulu V, Babu JS, Babu BH, Reddy MV. Terpenoids from a mangrove, Excoecaria agallocha. Acta Ciencia Indica Chem. 1993; 19:123-126.

Anjaneyulu ASR, Rao VL. Five diterpenoids (agallochins A-E) from the mangrove plant Excoecaria agallocha Linn. Phytochemistry. 2000; 55:891-901.

Anjaneyulu ASR, Rao VL, Sreedhar K. ent-Kaurane and beyerane diterpenoids from Excoecaria agallocha I. J Nat Prod. 2002; 65:382-385.

Anjaneyulu ASR, Rao VL. Seco-diterpenoids from Excoecaria agallocha. Phytochemistry. 2003; 62:585-589.

Anjaneyulu ASR, Rao VL, Sreedhar K. Agallochins JL, new isopimarane diterpenoids from Excoecaria agallocha L. Nat Prod Res. $2003 ; 17: 27-32$

Annam SC, Ankireddy M, Sura MB, Ponnapalli MG, Sarma AVS, Basha SJ. Epimeric excolides from the stems of Excoecaria agallocha and structural revision of rhizophorin A. Org Lett. 2015; 17:2840-2843.

Baba S, Chan HT, Aksornkoae S. Useful Products from Mangrove and other Coastal Plants. ISME Mangrove Educational Book Series No. 3, ISME and ITTO, Japan, 2013.

Babuselvam M, Ravikumar S, Farook KM, Abideen S, Mohamed MP, Uthiraselvam M. Evaluation of anti-inflammatory and analgesic effects on the extracts of different parts of Excoecaria agallocha L. J Appl Pharm Sci. 2012; 2:108-112.

Batsa AJS, Periyasamy K. Anticancer activity of Excoecaria agallocha leaf extract in cell line model. Int J Pharm Biol Sci. 2013; 3:392398.

Deepa M, Darsan MB, Ramalingam C. In vitro evaluation of the antioxidant, anti-inflammatory and antiproliferative activities of the leaf extracts of Excoecaria agallocha L. Int J Pharm Pharm Sci. 2015; 7:347352 .

Duke N. Australia's Mangroves: The Authoritative Guide to Australia's Mangrove Plants. University of Queensland, Brisbane, Queensland, Australia, 2006.

Erickson KL, Beutler JA, Cardellina II JH, McMahon JB. A novel phorbol ester from Excoecaria agallocha L. J Nat Prod. 1995; 58:769-772.

Giesen W, Wulfraat S, Zieren M, Scholten, L Mangrove Guidebook for Southeast Asia. FAO, Bangkok, Thailand, and Wetlands International, Wageningen, Netherlands, 2007.

Hossain SJ, Aoshima H, El-Sayed M, Ahmed F. Antioxidative and anti-histamine-release activities of Excoecaria agallocha L. PharmacologyOnline. 2009; 2:927-936

Huang J, Xu J, Wang Z, Khan D, Niaz SI, Zhu Y, Lin Y, Li J, Liu L. New lasiodiplodins from mangrove endophytic fungus Lasiodiplodia sp. 318. Nat Prod Res. 2017; 31:326-332.

Jahan IA, Hossain H, Akbar PN, Rahman MM, Khan TA, Rahman SE, Siraj MA. Antioxidant properties and HPLC assay of bioactive polyphenols of the ethanol extract of Excoecaria agallocha stem bark growing in Bangladesh. Brit J Pharm Res. 2014; 4:2116-2125.

Kaliamurthi S, Selvaraj G. Insight on Excoecaria agallocha: An overview. Nat Prod Chem Res. 2016; 4:6 pp.

Kamruzzaman M, Ahmed S, Paul S, Rahman MM, Osawa A. Stand structure and carbon storage in the oligohaline zone of the Sundarbans mangrove forest, Bangladesh. For Sci Technol. 2018; 14:23-28.

Kang J, Chen RY, Yu DQ. A new isopimarane-type diterpene and a new natural atisane-type diterpene from Excoecaria agallocha. J Asian Nat Prod Res. 2005; 7:729-734.

Karalai C, Wiriyachitra P, Opferkuch HJ, Hecker E. Cryptic and free skin irritants of the daphnane and tigliane types in latex of Excoecaria agallocha. Planta Med. 1994; 60:351-355.
Karuppiah V, Thiruganasambandam R. Antibiofilm and quorum sensing inhibitory potential of Excoecaria agallocha against Pseudomonas aeruginosa. Int J Sci Invent Today. 2017; 6:758-771.

Kasawani I, Kamaruzaman J, Nurun-Nadhirah MI. Biological diversity assessment of Tok Bali mangrove forest, Kelantan, Malaysia. WSEAS Trans Environ Dev. 2007; 3:37-44.

Kawashima T, Takahashi T, Inoue $\mathrm{Y}$, Kodama M, Ito S. Constituents of Excoecaria agallocha. Phytochemistry. 1971; 10:33083309.

Konishi T, Azuma M, Itoga R, Kiyosawa S, Fujiwara Y, Shimada Y. Three new labdane-type diterpenes from wood, Excoecaria agallocha. Chem Pharm Bull. 1996a; 44:229-231.

Konishi T, Kiyosawa S, Konoshima T, Fujiwara Y. Chemical structures of excoecarins A, B and C: Three new labdane-type diterpenes from wood, Excoecaria agallocha. Chem Pharm Bull. 1996b; 44:21002102.

Konishi T, Fujiwara Y, Konishima T, Kiyosawa S. Five new labdane-type diterpenes from Excoecaria agallocha L. Chem Pharm Bull. 1998a; 46:1393-1398.

Konishi T, Konoshima T, Fujiwara Y, Kiyosawa S. Stereostructure of excoecarin H, a novel seco-labdane-type diterpene from Excoecaria agallocha. Chem Pharm Bull. 1998b; 46:721-722.

Konishi T, Takasaki M, Tokuda H, Kiyosawa S, Konoshima T. Anti-tumour-promoting activity of diterpenes from Excoecaria agallocha. Biol Pharm Bull. 1998c; 21:993-996.

Konishi T, Konoshima T, Fujiwara Y, Kiyosawa S, Miyahara K, Nishi M. Stereostructures of new labdane-type diterpenes, excoecarins F, G1, and G2 from the wood of Excoecaria agallocha. Chem Pharm Bull. 1999; 47:456-458.

Konishi T, Konoshima T, Maoka T, Fujiwara Y. Novel diterpenes, excoecarins $\mathrm{M}$ and $\mathrm{N}$ from the resinous wood of Excoecaria agallocha. Tetrahedron Lett. 2000a; 41:3419-3422.

Konishi T, Konoshima T, Fujiwara Y, Kiyosawa S. Excoecarins D, E and K, from Excoecaria agallocha. J Nat Prod. 2000b; 63:344-346.

Konishi T, Yamazoe K, Konoshima T, Maoka T, Fujiwara Y, Miyahara K. New bis-seco-labdane diterpenoids from Excoecaria agallocha. J Nat Prod. 2003a; 66:108-111.

Konishi T, Yamazoe K, Konoshima T, Fujiwara Y. Seco-labdane type diterpenes from Excoecaria agallocha. Phytochemistry. 2003b; 64:835-840.

Konishi T, Yamazoe K, Kanzato M, Konoshima T, Fujiwara Y. Three diterpenoids (Excoecarins V1-V3) and a flavanone glycoside from the fresh stem of Excoecaria agallocha. Chem Pharm Bull. 2003c; 51:11421146.

Konoshima T, Konishi T, Takasaki M, Yamazoe K, Tokuda H. Anti-tumour-promoting activity of the diterpene from Excoecaria agallocha III. Biol Pharm Bull. 2001; 24:1440-1442.

Kumarasinghe SP, Seneviratne R. Skin and eye injury due to latex of Excoecaria agallocha. Aust J Dermatol. 1998; 39:275-276.

Laith AA, Mazlan AG, Effendy AW, Ambak MA, Nadirah M, Muhammad TS, Zain SM, Jabar A, Najiah M. Phytochemical composition and in vitro antimicrobial, antioxidant activities of methanolic leaf extracts from Excoecaria agallocha. Biosci Biotechnol Res Asia. 2016; 13:599-608.

Laith AA, Najiah M. Antimicrobial activities of blinding tree, Excoecaria agallocha against selected bacterial pathogens. J Microbiol Antimicrob. 2014; 6:29-36.

Laith AA, Mazlan AG, Effendy AW, Ambak MA, Nurhafizah WWI, Alia AS, Jabar A, Najiah M. Effect of Excoecaria agallocha on nonspecific immune responses and disease resistance of Oreochromis niloticus against Streptococcus agalactiae. Res Vet Sci. 2017; 112:192-200.

Li MY, Xiao Q, Pan JY, Wu J. Natural products from semimangrove flora: Source, chemistry and bioactivities. Nat Prod Rep. 2009; $26: 281-298$

Li X, Lei J, Zheng Y, Isabel S, Lin W. New entisopimarane diterpene from mangrove Excoecaria agallocha L. Chem Res Chin Uni. 2007; 23:541-543. 
Li Y, Liu J, Yu S, Proksch P, Gu J, Lin W. TNF- $\alpha$ inhibitory diterpenoids from the Chinese mangrove plant Excoecaria agallocha $\mathrm{L}$. Phytochemistry. 2010; 71:2124-2131.

Li Y, Yu S, Liu D, Proksch P, Lin W. Inhibitory effects of polyphenols toward $\mathrm{HCV}$ from the mangrove plant Excoecaria agallocha L. Bioorg Med Chem Lett. 2012; 22:1099-1102.

Liu Z, Jiang W, Deng ZW, Lin WH. Assignment of the absolute stereochemistry of an unusual diterpenoid from the mangrove plant Excoecaria agallocha L. J Chin Pharm Sci. 2010; 19:387-392.

Mendhulkar VD, Yeragi LA, Kumar H. Bioassay of vector larvae with latex of blind eye mangrove plant Excoecaria agallocha Linn. Int J Mosquito Res. 2017; 4:33-36.

Mondal S, Ghosh D, Ramakrishna K. A complete profile on blind-your-eye mangrove Excoecaria agallocha L. (Euphorbiaceae): Ethnobotany, phytochemistry and pharmacological aspects. Pharmacogn Rev. 2016; 10:123-138.

Nagababu P, Rao VU. Biosynthesis, characterization and antibacterial activity of silver nanoparticles of Excoecaria agallocha L. fruit extract. Int J Drug Delivery. 2017:9:3-8.

Patil RC, Manohar SM, Upadhye MV, Katchi VI, Rao AJ, Mule A, Moghe AS. Anti-reverse transcriptase and anticancer activity of stem ethanol extracts of Excoecaria agallocha (Euphorbiaceae). Ceylon J Sci. 2011; 40:147-155.

Patra JK, Mohapatra AD, Rath SK, Dhal NK, Thatoi H. Screening of antioxidant and antifilarial activity of leaf extracts of Excoecaria agallocha L. Int J Integr Biol. 2009; 7:9-15.

Ponnapalli MG, Ankireddy M, Annam SC, Ravirala S, Sukki S, Tuniki VR. Unusual ent-isopimarane-type diterpenoids from the wood of Excoecaria agallocha. Tetrahedron Lett. 2013; 54:2942-2945.

Poorna CA, Resmi MS, Soniya EV. In vitro antioxidant analysis and the DNA damage protective activity of leaf extract of the Excoecaria agallocha Linn. mangrove plant. Int J Agric Chem. 2012; 1:1-6.

Pradeepa P, Subalakshmi K, Saranya A, Dinesh P, Raj VA, Ramanathan T. Milky mangrove Excoecaria agallocha L. plant as a source for potential mosquito larvicides. J Appl Pharm Sci. 2015; 5:102-105.

Premanathan M, Nokashima H, Kathiresan K, Rajendran N, Yamamoto N. In vitro anti-human immunodeficiency virus activity of mangrove plants. Indian J Med Res. 1996; 103:278-281.

Ragavan P, Ravichandran K, Mohan PM, Saxena A, Prasanth RS, Jayaraj RSJ, Saravanan S. Note on Excoecaria indica (Willd.) Muell.Arg, 1863 (Euphorbiaceae), from the Andaman and Nicobar Islands, India; a data deficient species. Biodiversitas. 2015; 16:22-26.

Rahman M, Siddika A, Bhadra B, Rahman S, Agarwala B, Chowdhury MH, Rahmatullah M. Anti-hyperglycemic activity studies on methanol extract of Petrea volubilis L.(Verbenaceae) leaves and Excoecaria agallocha L. (Euphorbiaceae) stems. Adv Nat Appl Sci. 2010; 4:361-364.

Raja M, Ravikumar S, Gnanadesigan M, Vijayakumar V. In vitro antibacterial activity of diterpene and benzoxazole derivatives from Excoecaria agallocha L. Int J Biol Chem Sci. 2010; 4:692-701.

Rajeswari K, Rao TB. Excoecaria agallocha Linn (Euphorbiaceae): An overview. J Chem Pharm Res. 2015; 7:423-439.

Rajia S, Alamgir M, Shahriar M, Choudhuri MSK. Bioactivity of the methanol extract of Excoecaria agallocha Linn. (Euphorbiaceae). Orient Pharm Exper Med. 2006; 6:102-107.

Rifai Y, Arai MA, Sadhu SK, Ahmed F, Ishibashi M. New hedgehog/GLI signalling inhibitors from Excoecaria agallocha. Bioorg Med Chem Lett. 2011; 21:718-722.

Satyavani K, Gurudeeban S, Ramanathan T. Inhibitory effect of Excoecaria agallocha L. extracts on elastase and collagenase and identification of metabolites using HPLC-UV-MS techniques. Pharm Chem J. 2018; 51:960-964

Selvaraj G, Kaliamurthi S, Thirungnasambandam R, Vivekanandan L, Thangavel B. Anti-nociceptive effect in mice of thillai flavonoid rutin. Biomed Environ Sci. 2014; 27:295-299.

Shanmugapriya R, Ramanathan T. Assessment of cytotoxicity, antibacterial activity and phytochemical screening of acetone extract of Excoecaria agallocha L. (family: Euphorbiaceae) bark. Adv Res J Life Sci. 2015; 1:6-10.

Sofia S, Teresa MVM, Investigation of bioactive compounds and antioxidant activity of Excoecaria agallocha, L. Int J Pharm Sci Res. 2016; 7:5062-5066

Subhan N, Alam MA, Ahmed F, Abdul Awal M, Nahar L, Sarker SD. In vitro antioxidant property of the extract of Excoecaria agallocha (Euphorbiaceae). DARU. 2008a, 16:149-154

Subhan N, Alam MA, Ahmed F, Shahid IJ, Nahar L, Sarker SD. Bioactivity of Excoecaria agallocha. Brazil J Pharmacogn. 2008b; 18:521526 .

Subhan N, Alam A, Ahmed F, Israt Zahan Shahid IZ. Antinociceptive and gastroprotective effect of the crude ethanolic extracts of Excoecaria agallocha Linn. Turk J Pharm Sci. 2008c; 5:143-154

The Plant List, Excoecaria. 2013. Database available at: http:// www.theplantlist.org.

Thirumurugan G, Vijayakumar TM, Poovi G, Senthilkumar K, Sivaraman K, Dhanaraju MD. Evaluation of antidiabetic activity of Excoecaria agallocha $\mathrm{L}$. in alloxan-induced diabetic mice. Nat Prod Indian J. 2009; 6:1-5.

Thirunavukkarasu P, Ramanathan T, Renugadevi G, Jayalakshmi S. Studies on larvicidal potential of Excoecaria agallocha L. bark extract. J Pharm Res. 2011; 4:3480-3482.

Thirunavukkarasu P, Ramkumar L, Ramanathan T. Anti-ulcer activity of Excoecaria agallocha bark on NSAID-induced gastric ulcer in albino rats. Global J Pharmacol. 2009; 3:123-126.

Tian MQ, Bao GM, Ji NY, Li XM. Wang BG. Triterpenoids and steroids from Excoecaria agallocha. China J Chin Mater Med. 2008; $33: 405-408$

Vadlapudi V, Bobbarala V, Penumajji S, Naidu KC. Excoecaria agallocha L. antimicrobial properties against important pathogenic microorganisms. Int J ChemTech Res. 2009; 1:865-867.

Vijayan V, Rahees N, Vidyasagaran K. Plant diversity and structural dynamics of mangroves in the southwest coast of Kerala, India Appl Ecol Environ Res. 2015; 13:1055-1067.

Wang JD, Xiang WS, Guo YW. Agallochaols A and B, two new diterpenes from the Chinese mangrove Excoecaria agallocha. Helv Chim Acta. 2004; 87:2829-2833

Wang JD, Li ZY, Guo YW. Secoatisane- and isopimarane-type diterpenoids from the Chinese mangrove Excoecaria agallocha L. Helv Chim Acta. 2005; 88:979-985.

Wang JD, Li ZY, Xiang WS, Guo YW. Further new secoatisane diterpenoids from the Chinese mangrove Excoecaria agallocha L. Helv Chim Acta. 2006; 89:1367-1372.

Wang JD, Zhang W, Li ZY, Xiang WS, Guo YW, Krohn, K. Elucidation of excoagallochaols A-D, four unusual diterpenoids from the Chinese mangrove Excoecaria agallocha. Phytochemistry. 2007; 68:24262431.

Wang ZC, Lin YM, Feng DQ, Ke CH, Lin P, Yan CL, Chen JD. A new atisane-type diterpene from the bark of the mangrove plant Excoecaria agallocha. Molecules. 2009; 14:414-422.

Yin B, Shen L, Zhang M, Zhao L, Wang Y, Huo C, Shi Q. Chemical constituents of plants from the genus Excoecaria. Chem Biodiver. 2008; 5:2356-2371.

Zou JH, Dai JG, Chen XG, Yuan JQ. Pentacyclic triterpenoids from leaves of Excoecaria agallocha. Chem Pharm Bull. 2006; 54:920-921.

How to cite this article:

Chan EWC, Oshiro N, Kezuka M, Kimura N, Baba K, Chan HT. Pharmacological potentials and toxicity effects of Excoecaria agallocha. J App Pharm Sci, 2018; 8(05): 166-173. 